\title{
PEMBINAAN DAN PENGESAHAN INSTRUMEN PENGETAHUAN, AFEKTIF DAN MOTIVASI GURU SAINS TERHADAP PENGAJARAN DAN PEMBELAJARAN STEM (PAMPDPSTEM)
}

\section{DEVELOPMENT AND EVALUATION OF INSTRUMEN KNOWLEDGE, AFFECTIVE AND MOTIVATION OF SCIENCE TEACHERS' TOWARDS STEM TEACHING AND LEARNING (PAMPDPSTEM)}

\author{
Aminah Binti Jekri' \\ Faculty of Psychology and Education, Universiti Malaysia Sabah (UMS), Malaysia. \\ (Email: MP1811147T@ student @ums.edu.my) \\ Crispina Gregory K Han ${ }^{2}$ \\ Unit For Rural Education Research, Faculty of Psychology and Education, \\ Universiti Malaysia Sabah (UMS), Malaysia. \\ (Email: crispina@ums.edu.my)
}

Received date: $21-05-2019$

Revised date: 16-07-2019

Accepted date: $22-07-2019$

Published date: 12-09-2019

To cite this document: Jekri, A., \& Han, C. G. K. (2019). Pembinaan dan Pengesahan Instrumen Pengetahuan, Afektif dan Motivasi Guru Sains terhadap Pengajaran dan Pembelajaran STEM (PAMPDPSTEM). International Journal of Education, Psychology and Counseling, 4 (32), 79-89.

DOI: $10.35631 /$ IJEPC.432009

\begin{abstract}
Abstrak: Tujuan kajian ini adalah untuk membangunkan dan mengesahkan instrumen PAMPDPSTEM untuk menilai pengetahuan, afektif dan motivasi guru sains terhadap pelaksanaan PdP STEM di Sekolah Menengah. Berdasarkan kajian literatur dan analisis instrumen sedia ada, konstruk dikenalpasti dan item yang menyumbang kepada pelaksanaan PdP STEM telah dibangunkan. Instrumen ini terdiri daripada Soal Selidik Aspek Pengetahuan (SSAP), Soal Selidik Aspek Afektif (SSAA), Soal Selidik Aspek Motivasi (SSAM) dan Soal Selidik Tahap Pelaksanaan PdP STEM (SSTP). Kesahan kandungan instrumen melibatkan empat orang pakar. Manakala, Kesahan gagasan dan kebolehpercayaan instrumen telah disemak dengan menganalisis item-item soal selidik menggunakan perisian Statistical Package of Social Science (SPSS) Versi 23.0. Seramai 104 orang guru telah terlibat dalam kajian ini. Muatan faktor untuk setiap item adalah dalam julat 0.547 hingga 0.930 dan nilai kebolehpercayaan (alpha) adalah dalam julat 0.840 hingga 0.930. Keputusan kesahan dan kebolehpercayaan ini menunjukkan instrumen sesuai digunakan untuk kajian sebenar.
\end{abstract}


Dapatan kajian ini jelas menunjukkan instrumen ini mempunyai kesahan dan kebolehpercayaan yang tinggi dan boleh digunapakai dalam kajian sebenar.

Kata Kunci: Pengetahuan, Afektif, Motivasi, Pengajaran dan Pembelajaran STEM

Abstract: This study aims to develop and validate an instrument (PAMPDPSTEM) for assessing the knowledge, affective and motivation of science teacher in implementing STEM teaching and learning at secondary school. Based on literatures review and analysis of existing instruments, the constructs were determine and items which contribute to the implementation of STEM teaching and learning were develop. The instrument consists of Soal Selidik Aspek Pengetahuan (SSAP), Soal Selidik Aspek Afektif (SSAA), Soal Selidik Aspek Motivasi (SSAM) and Soal Selidik Tahap Pelaksanaan PdP STEM (SSTP). The instrument content validity has involved four experts. While for construct validity and reliability test, the data was analysed by using the Statistical Package of Social Science (SPSS) software Version 23.0. A total of 104 teachers participated in this study. The factor loading for each item ranges from 0.547 - 0.930, while the realibility was within $0.840-0.930$. The validity and reliability results obtained indicate that the instrument is valid and reliable for actual study.

Keywords: Knowledge, Affective, Motivation, STEM Teaching and Learning

\section{Pengenalan}

Pendidikan sains mengalami transformasi apabila Kurikulum Standard Sekolah Menengah (KSSM) diperkenalkan bermula dari Tingkatan Satu pada tahun 2017. Merujuk Surat Pekeliling Ikhtisas KPM Bilangan 9 (2016), KSSM yang menggantikan Kurikulum Bersepadu Sekolah Menengah (KBSM) dilaksanakan secara berperingkat dan melibatkan semua sekolah menengah dalam sistem pendidikan kebangsaan. Objektif utama KSSM adalah untuk melahirkan modal insan yang berfikir secara kritis, kreatif dan inovatif serta mampu berdaya saing di peringkat antarabangsa dan global. KSSM memfokuskan pembelajaran secara inkuiri, penyelesaian masalah, pembelajaran kontekstual, pembelajaran kolaboratif, pembelajaran berasaskan projek dan pendekatan sains, teknologi, kejuruteraan dan matematik (STEM) dalam pengajaran dan pembelajaran (PdP) sains.

Pelaksanaan STEM dalam pengajaran dan pembelajaran (PdP) di negara kita bermula apabila Kementerian Pendidikan Malaysia (KPM) melancarkan Pelan Pembangunan Pendidikan Malaysia (PPPM 2013-2025) pada 6 September 2012. Transformasi pendidikan dalam tempoh 13 tahun ini akan dilaksanakan menerusi tiga gelombang dan melibatkan 11 anjakan. Anjakan pertama memfokuskan kesamarataan akses kepada pendidikan berkualiti bertaraf antarabangsa. Salah satu objektif dalam anjakan pertama yang ingin dicapai ialah meningkatkan kualiti pendidikan negara dalam STEM (Pelan Pembangunan Pendidikan Malaysia, 2012).

\section{Pernyataan Masalah}

Merujuk statistik yang dikeluarkan oleh Kementerian Pendidikan Tinggi, jumlah bilangan enrolmen bagi sesi kemasukan 2016-2017 di universiti awam (UA) adalah seramai 538, 555 pelajar. Daripada jumlah tersebut, hanya 276, 235 pelajar mengambil kursus atau bidang berkaitan STEM (Statistik Pendidikan Tinggi, 2017). Senario ini menyebabkan negara bakal berhadapan krisis kekurangan tenaga kerja mahir sebanyak 236,000 menjelang tahun 2020 (Utusan Malaysia, 2017). Menurut Unesco International Bureau of Education salah satu 
faktor yang mungkin dapat meningkatkan jumlah enrolmen murid dalam bidang STEM adalah pelaksanaan STEM dalam PdP di peringkat sekolah. Namun begitu, kajian mendapati pelaksanaan pendidikan STEM masih tidak memuaskan atau berada di tahap minima.

Menurut kajian Pimthong dan Williams (2018), tahap pelaksanaan PdP STEM yang minima disebabkan guru kurang pengetahuan. Kenyataan ini turut disokong oleh kajian yang dijalankan oleh Muhamad Abdul Hadi Bunyimin (2014), Nur Farhana Ramli dan Otman Talib (2017), Edy Hafizan et al. (2015) dan Titik Rahayu et al., (2018). Berdasarkan kajian yang dijalankan oleh Siti Najihah et al.,(2017) dan Ahmad Zamri (2017) kekurangan pengetahuan ini menyebabkan tahap kefahaman dan kesediaan guru dalam pelaksanaan PdP STEM rendah dan seterusnya menyebabkan pelaksanaan PdP STEM pada tahap yang minima. Selain itu, menurut Stohlmann et al. (2012), faktor sikap guru dari aspek afektif turut mempengaruhi pelaksanaan pendidikan integrasi STEM. Pendapat ini disokong oleh Abdul Halim Abdullah et al.( 2017). Menurut Kubat (2018), faktor afektif seperti kegembiraan guru menjalankan PdP dapat meningkatkan tahap pelaksanaan PdP STEM. Di samping itu, aspek motivasi guru turut mempunyai hubungan positif dengan pelaksanaan inovasi kurikulum seperti pendidikan STEM (Gorozidis dan Papaioannou, 2013). Pendapat ini turut disokong oleh Abdul Halim Abdullah et al. (2017) yang menyatakan tahap kesediaan guru yang tinggi dapat mewujudkan motivasi dalam diri guru untuk melaksanakan pendidikan STEM.

Secara umumnya, tidak terdapat instrumen yang menggabungkan empat aspek atau konstruk iaitu pengetahuan, afektif dan motivasi terhadap pelaksanaan PdP STEM dalam konteks sistem pendidikan Malaysia yang sebenar. Maka, untuk aspek pengetahuan, pengkaji telah membangunkan Soal selidik Tahap Pengetahuan Guru berkaitan PdP STEM (SSAP). Bahagian ini mengandungi 10 item berbentuk soalan berbentuk objektif. Pemilihan soalan objektif adalah untuk memastikan data yang diperolehi berkaitan pengetahuan pedagogi asas guru berkaitan PdP STEM adalah lebih tepat. Item dalam soal selidik ini dibina oleh pengkaji dengan merujuk Panduan Pelaksanaan STEM dalam Pembelajaran dan Pengajaran, 2016 dan Dokumen Standard Kurikulum dan Pentaksiran (DSKP).

Bagi aspek afektif pula, pengkaji telah merujuk instrumen berkaitan sikap dan komponennya iaitu Dimensions of Attitude Towards Science (DAS) yang dibangunkan oleh AalderenSmeets dan Molen (2013). Oleh kerana aspek sikap adalah terlalu umum dan luas, maka pengkaji hanya memfokuskan kajian terhadap komponen afektif dalam sikap. Justeru itu , pengkaji telah merujuk dan mengubahsuai instrumen ini untuk membina Soal Selidik Aspek Afektif (SSAA) yang mengandungi 10 item. Dalam kajian ini, komponen afektif terdiri daripada aspek kegembiraan dan kerisauan guru ketika melaksanakan PdP STEM. SSAA mengandungi 10 item berkaitan komponen afektif.

Manakala soal selidik berkaitan aspek motivasi pula diadaptasi daripada instrumen asal iaitu Teresa Amabile's Inventory on Work Motivation yang dibangunkan oleh Amabile et al. (1994). Instrumen ini menilai motivasi intrinsik dan ekstrinsik guru dalam pengajaran. Dalam Soal Selidik Aspek Motivasi (SSAM) yang dibina oleh pengkaji, terdapat 10 item yang menilai motivasi intrinsik dan ekstrinsik guru dalam pelaksanaan PdP STEM.

Seterusnya, pengkaji juga membina Soal Selidik Aspek Pelaksanaan PdP STEM (SSAP) untuk menilai tahap pelaksanaan PdP STEM di Malaysia. Soal selidik ini telah diadaptasi daripada Soal Selidik Persepsi Guru-Guru Sekolah Terhadap STEM yang dihasilkan oleh Akademi Sains Malaysia. Pada tahun 2017, borang soal selidik ini telah diguna pakai 
diseluruh Malaysia untuk mendapatkan maklum balas daripada guru-guru berkaitan dengan pelaksanaan PdP STEM. Instrumen asal mengandungi empat bahagian iaitu maklumat responden, persepsi umum terhadap STEM, STEM dalam PdP, dan pembudayaan STEM dalam sains. Dalam kajian ini, SSAP hanya mengandungi tiga subskala iaitu kekerapan pelaksanaan PdP STEM dalam subjek sains, cabaran dalam melaksanakan PdP STEM serta cadangan penambahbaikan.

Justeru itu, melalui kajian ini, penyelidik ingin membangunkan dan mengesahkan instrumen yang akan memberi maklumat berkaitan tahap pengetahuan, afektif dan motivasi guru sains terhadap pelaksanaan PdP STEM mengikut konteks atau acuan sistem pendidikan Malaysia.

\section{Tujuan Kajian}

Kajianini bertujuan untuk menguji kesahan dan kebolehpercayaan instrumen yang telah dibina dan juga yang diadaptasi.

\section{Reka Bentuk Kajian dan Metodologi}

Kajian ini menggunakan reka bentuk kajian kuantitatif iaitu jenis tinjauan. Penyelidik telah mengedarkan borang soal selidik kepada 105 orang guru sains di enam buah sekolah menengah Daerah Penampang dan tujuh buah sekolah menengah Daerah Tuaran. Pemilihan lokasi kajian adalah berasaskan dua faktor iaitu lokasi sekolah dan kategori sekolah. Hanya 3 daripada 13 sekolah yang dipilih terletak di kawasan bandar. Manakala 10 buah sekolah yang lain terletak di kawasan luar bandar. Sekolah - sekolah yang terpilih juga terdiri daripada 3 kategori iaitu sekolah harian biasa, sekolah agama dan sekolah berasrama penuh. Lokasi kajian dipilih dengan teliti agar instrumen yang dibina sesuai diaplikasikan kepada semua guru sains. Responden dipilih dengan menggunakan teknik pensampelan rawak mudah. Daripada 105 set soal selidik yang diagihkan, hanya 100 set borang soal selidik telah dikembalikan dengan lengkap.

\section{Instrumen Soal Selidik}

Instrumen kajian yang dibina mempunyai lima bahagian iaitu Bahagian A berkaitan demografi guru, Soal Selidik Aspek Pengetahuan (SSAP), Soal Selidik Aspek Afektif (SSAA), Soal Selidik Aspek Motivasi (SSAM) dan Soal Selidik Tahap Pelaksanaan (SSTP). SSAP terdiri daripada 10 item soalan aneka pilihan dan beraras pengetahuan dan pemahaman sahaja. Manakala SSAA, SSAM dan SSTP pula dibina menggunakan skala Likert lima mata iaitu Sangat Tidak Setuju (STS), Tidak Setuju (TS), Tidak Pasti (TP), Setuju (S) dan Sangat Setuju (SS). Skala lima mewakili SS manakala skala satu pula melambangkan STS.

\section{Prosedur Pembinaan Instrumen}

Proses pembinaan Instrumen PAMPDPSTEM ini melibatkan tiga peringkat iaitu mengenalpasti konstruk utama berkaitan pelaksanaan PdP STEM semasa, pembinaan item berdasarkan konstruk yang dipilih dan menjalankan kajian dan analisis data. Proses dalam setiap peringkat adalah seperti yang dinyatakan oleh Walker dan Fraser (2005).

\section{Peringkat Pertama: Mengenalpasti konstruk utama}

Dalam kajian ini, terdapat dua langkah yang dijalankan oleh pengkaji. Langkah pertama melibatkan kajian literatur yang berkaitan dengan pelaksanaan PdP STEM atau pendidikan STEM semasa. Literatur ini meliputi jurnal dan artikel kajian lepas dalam dan luar negara. Langkah ini penting kerana dapat membantu pengkaji mengenalpasti aspek yang mungkin 
mempengaruhi pelaksanaan PdP STEM. Akhirnya, pengkaji telah memilih tiga aspek iaitu pengetahuan, afektif dan motivasi guru sains.

Langkah kedua pula memerlukan pengkaji meneliti instrumen sedia ada yang berkaitan dengan aspek atau konstruk yang telah dipilih. Langkah ini penting sebagai panduan dan rujukan utama pengkaji dalam membina item- item yang bersesuaian.

\section{Peringkat Kedua: Pembinaan item dalam setiap konstruk}

Peringkat kedua pula melibatkan dua langkah. Langkah pertama adalah mengadaptasi beberapa item yang bersesuaian daripada instrumen sedia ada berkaitan pelaksanaan PdP STEM atau pendidikan STEM. Dalam instrumen ini, soal selidik bagi konstruk pengetahuan telah dibina oleh penyelidik memandangkan tidak terdapat soal selidik yang berkaitan dengan situasi semasa PdP STEM di Malaysia. Pembinaan item ini berpandukan dokumen Pelaksanaan PdP STEM dan Bahan STEM Sains Sekolah Menengah yang diterbitkan oleh Bahagian Pembangunan Kurikulum (BPK).

Seterusnya, langkah kedua pula memerlukan pengkaji mendapatkan kesahan kandungan daripada empat orang pakar yang terdiri daripada dua pensyarah Universiti Malaysia Sabah (UMS), school improvement specialist coach (SISC+) dan seorang guru cemerlang sains teras. Pemilihan pakar adalah berdasarkan pengalaman dalam bidang STEM dan pengajaran sains serta pembinaan instrumen. Kemudian, pengkaji menjalankann penambahbaikan terhadap instrumen yang disemak. Jadual 1 menunjukkan instrumen pengetahuan, motivasi dan afektif pelaksanaan PdP STEM.

Jadual 1: Bilangan Konstruk dan Item Instrumen PAMPDPSTEM

\begin{tabular}{clcc}
\hline Konstruk & \multicolumn{1}{c}{ Dimensi kajian } & Bilangan item \\
& \multicolumn{1}{c}{ 1. Ciri - ciri PdP STEM } & 4 \\
\hline Pengetahuan & 2. Elemen STEM dalam PdP sains & 3 \\
& 3. Pembudayaan PdP STEM & 4 \\
\hline Afektif & 1. Kegembiraan & Jumlah item & 10 \\
& 2. Kerisauan & 6 \\
\hline & & Jumlah item & 10 \\
\hline Motivasi & 1. Faktor intrinsik & & 6 \\
& 2. Faktor Ekstrinsik & 4 \\
\hline & & Jumlah item & 10 \\
\hline Pelaksanaan & 1. Kekerapan & 4 \\
PdP STEM & 2. Cabaran & 3 \\
& 3. Penambahbaikan & 3 \\
\hline & & Jumlah item & 10 \\
\hline & Jumlah keseluruhan item dalam instrumen & 40 \\
\hline
\end{tabular}

Peringkat ketiga: Menjalankan Kajian Sebenar

Peringkat ketiga melibatkan dua langkah. Langkah pertama ialah mentadbir instrumen yang telah dibina berdasarkan saiz sampel yang telah ditetapkan. Penentuan saiz sampel adalah 
menggunakan perisian $G^{*}$ Power. Secara keseluruhannya, kajian ini melibatkan 105 orang guru sains sekolah menengah yang terdiri daripada tiga kategori sekolah yang berbeza.

Seterusnya, langkah kedua pula melibatkan analisis faktor. Tujuan analisis faktor dijalankan adalah untuk mengesahkan konstruk - konstruk yang telah dipilih. Kesahan kosntruk adalah sesuai dan wajar digunakan untuk mengesahkan instrumen yang telah dibina (Nunally, 1978).

\section{Perbincangan}

\section{Ujian Kenormalan Data Rintis.}

Menurut Chua Yan Piaw (2014), data mempunyai taburan yang normal sekiranya nilai skewness dan kurtosis berada dalam julat -1.96 hingga +1.96 . Selain itu, nilai bagi Ujian Kolmogorov- Smirnov dan Ujian Shapiro-Wilk perlu > .05 untuk memastikan data bertabur secara nomal (Nor Aishah Ahad et al., 2011). Jadual 2 menunjukkan nilai skewness dan kurtosis, dan nilai signifikan Ujian Kolmogorov-Smirnov dan Ujian Shapiro-Wilk berada dalam julat yang dinyatakan. Justeru itu, taburan data dalam kajian ini menunjukkan kenormalan yang baik.

Jadual 2: Nilai Skewness dan Kurtosis, Signifikan KolmogorovSmirnov, dan Signifikan Shapiro-Wilk.

\begin{tabular}{|c|c|c|c|c|c|c|c|c|}
\hline & \multirow[t]{2}{*}{$\begin{array}{c}\text { Skewnes } \\
\text { s }\end{array}$} & \multirow[t]{2}{*}{$\begin{array}{c}\text { kurtosi } \\
\quad \mathrm{s}\end{array}$} & \multicolumn{3}{|c|}{$\begin{array}{c}\text { Kolmogorov- } \\
\text { Smirnov }^{\mathbf{a}}\end{array}$} & \multicolumn{3}{|c|}{ Shapiro-Wilk } \\
\hline & & & $\begin{array}{l}\text { Statisti } \\
\text { c }\end{array}$ & df & Sig & $\begin{array}{l}\text { Statisti } \\
\text { c }\end{array}$ & df & $\begin{array}{c}\text { Sig } \\
\text { • }\end{array}$ \\
\hline Pengetahua & -.217 & -.106 & .078 & 10 & .07 & .902 & 10 & .17 \\
\hline $\mathrm{n}$ & & & & 0 & 5 & & 0 & 1 \\
\hline Afektif & -.791 & .636 & .139 & 10 & .09 & .867 & 10 & .10 \\
\hline & & & & 0 & 1 & & 0 & 4 \\
\hline Motivasi & .710 & -.308 & .159 & 10 & .13 & .955 & 10 & .28 \\
\hline & & & & 0 & 4 & & 0 & 4 \\
\hline Tahap & -.304 & .903 & .067 & 10 & .20 & .924 & 10 & .22 \\
\hline $\begin{array}{c}\text { Pelaksanaa } \\
\mathrm{n}\end{array}$ & & & & 0 & 0 & & 0 & 5 \\
\hline
\end{tabular}

\section{Keputusan Analisis Faktor}

Analisis faktor dijalankan dengan menggunakan kaedah extraction of principal component dengan varimax rotation dijalankan ke atas setiap 10 item yang mengukur konstruk pengetahuan, afektif dan motivasi guru serta tahap pelaksanaan PdP STEM. Nilai signifikan bagi sukatan kecukupan pensampelan Kaiser-Meyer-Olkin (KMO) dan nilai Ujian Kesferaan Bartlett diteliti sebelum analisis faktor dijalankan. Menurut An Gie Yong dan Pearce (2013), nilai KMO >0.5 dan nilai ujian kesferaan Bartlett yang cukup besar menunjukkan suatu data memenuhi syarat kebolehfaktoran. Jadual 3 menunjukkan nilai signifikan bagi ujian KMO dan Ujian Kesferaan Bartlett kajian ini. Keputusan menunjukkan data ini memenuhi syarat kebolehfaktoran dan analisis faktor diteruskan dengan prosedur penyingkiran item. 
Jadual 3: Nilai Kaiser Meyer Olkin dan Signifikan Konstruk

\begin{tabular}{|c|c|c|c|c|c|}
\hline \multirow[t]{2}{*}{ Konstruk } & \multirow{2}{*}{$\begin{array}{l}\text { Kaiser-Meyer- } \\
\text { Olkin Measure of } \\
\text { Sampling } \\
\text { Adequacy }\end{array}$} & \multirow{2}{*}{$\begin{array}{c}\text { Bilangan } \\
\text { Item }\end{array}$} & \multicolumn{3}{|c|}{ Bartlett's Test of Sphericity } \\
\hline & & & $\begin{array}{c}\text { Approx. } \\
\text { Chi- Square }\end{array}$ & dff & Sig. \\
\hline Pengetahuan Guru & .637 & 10 & 721.370 & 45 & .000 \\
\hline Afektif Guru & .690 & 10 & 1205.987 & 45 & .000 \\
\hline Motivasi Guru & .706 & 10 & 1254.709 & 45 & .000 \\
\hline Tahap & .790 & 10 & 726.337 & 45 & .000 \\
\hline $\begin{array}{c}\text { Pelaksanaan PdP } \\
\text { STEM }\end{array}$ & & & & & \\
\hline
\end{tabular}

\section{Keputusan Bilangan Komponen dan Total Variance Explained}

Jadual 4, 5, 6, dan 7 menunjukkan keputusan dimensi atau komponen dan Total Variance Explained bagi SSAP, SSAA, SSAM dan SSTP. Jumlah keseluruhan varians bagi mengukur konstruk pengetahuan guru adalah $72.593 \%$, konstruk afektif guru adalah $73.356 \%$, konstruk motivasi guru adalah $75.199 \%$ dan konstruk tahap pelakasanaan PdP STEM adalah $77.599 \%$. Keputusan menunjukkan bahawa bilangan komponen dan item bagi setiap komponen adalah bersesuaian untuk mengukur kesemua konstruk kerana jumlah varians keseluruhan adalah melebihi 50\% (Merenda, 1997). Berdasarkan keputusan tersebut, terdapat tiga faktor utama yang memberi sumbangan besar kepada perubahan varians secara keseluruhan dalam konstruk pengetahuan guru dan tahap pelaksanaan PdP STEM dan dua faktor utama yang menyumbang kepada konstruk afektif guru dan konstruk motivasi guru.

Jadual 4: Keputusan Bilangan Komponen dan Total Variance Explained SSAP

\begin{tabular}{|c|c|c|c|c|c|c|}
\hline \multirow[b]{2}{*}{ Component } & \multicolumn{3}{|c|}{$\begin{array}{l}\text { Extraction Sums of Squared } \\
\text { Loadings }\end{array}$} & \multicolumn{3}{|c|}{$\begin{array}{c}\text { Rotation Sums of Squared } \\
\text { Loadings }\end{array}$} \\
\hline & Total & $\begin{array}{c}\% \text { of } \\
\text { Variance }\end{array}$ & $\begin{array}{c}\text { Cumulativ } \\
\text { e } \%\end{array}$ & Total & $\begin{array}{c}\% \text { of } \\
\text { Variance }\end{array}$ & $\begin{array}{c}\text { Cumulative } \\
\%\end{array}$ \\
\hline 1 & 4.484 & 44.839 & 44.839 & 2.921 & 29.214 & 29.214 \\
\hline 2 & 1.642 & 16.419 & 61.258 & 2.413 & 24.132 & 53.346 \\
\hline 3 & 1.133 & 11.335 & 72.593 & 1.925 & 19.247 & 72.593 \\
\hline
\end{tabular}

Jadual 5: Keputusan Bilangan Komponen dan Total Variance Explained SSAA

\begin{tabular}{|c|c|c|c|c|c|c|}
\hline \multirow[b]{2}{*}{ Component } & \multicolumn{3}{|c|}{$\begin{array}{l}\text { Extraction Sums of Squared } \\
\text { Loadings }\end{array}$} & \multicolumn{3}{|c|}{$\begin{array}{c}\text { Rotation Sums of Squared } \\
\text { Loadings }\end{array}$} \\
\hline & Total & $\begin{array}{c}\% \text { of } \\
\text { Variance }\end{array}$ & $\underset{\%}{\text { Cumulative }}$ & Total & $\begin{array}{c}\% \text { of } \\
\text { Variance }\end{array}$ & $\underset{\%}{\text { Cumulative }}$ \\
\hline 1 & 6.079 & 60.788 & 60.788 & 4.147 & 41.466 & 41.466 \\
\hline 2 & 1.257 & 12.568 & 73.356 & 3.189 & 31.891 & 73.356 \\
\hline
\end{tabular}


Jadual 6: Keputusan Bilangan Komponen dan Total Variance Explained SSAM

\begin{tabular}{|c|c|c|c|c|c|c|}
\hline \multirow[b]{2}{*}{ Component } & \multicolumn{3}{|c|}{$\begin{array}{c}\text { Extraction Sums of Squared } \\
\text { Loadings }\end{array}$} & \multicolumn{3}{|c|}{$\begin{array}{c}\text { Rotation Sums of Squared } \\
\text { Loadings }\end{array}$} \\
\hline & Total & $\begin{array}{c}\% \text { of } \\
\text { Variance }\end{array}$ & $\underset{\%}{\text { Cumulative }}$ & Total & $\begin{array}{c}\% \text { of } \\
\text { Variance }\end{array}$ & $\underset{\%}{\text { Cumulative }}$ \\
\hline 1 & 6.352 & 63.519 & 63.519 & 4.465 & 44.652 & 44.652 \\
\hline 2 & 1.168 & 11.680 & 75.199 & 3.055 & 30.547 & 75.199 \\
\hline
\end{tabular}

Jadual 7: Keputusan Bilangan Komponen dan Total Variance Explained SSTP

\begin{tabular}{|c|c|c|c|c|c|c|}
\hline \multirow[b]{2}{*}{ Component } & \multicolumn{3}{|c|}{$\begin{array}{c}\text { Extraction Sums of Squared } \\
\text { Loadings } \\
\end{array}$} & \multicolumn{3}{|c|}{$\begin{array}{c}\text { Rotation Sums of Squared } \\
\text { Loadings }\end{array}$} \\
\hline & Total & $\begin{array}{c}\% \text { of } \\
\text { Variance }\end{array}$ & $\begin{array}{c}\text { Cumulative } \\
\%\end{array}$ & Total & $\begin{array}{c}\% \text { of } \\
\text { Variance }\end{array}$ & $\begin{array}{c}\text { Cumulative } \\
\%\end{array}$ \\
\hline 1 & 5.153 & 51.530 & 51.530 & 3.003 & 30.028 & 30.028 \\
\hline 2 & 1.424 & 14.236 & 65.766 & 2.611 & 26.114 & 56.143 \\
\hline 3 & 1.183 & 11.833 & 77.599 & 2.146 & 21.456 & 77.599 \\
\hline
\end{tabular}

\section{Keputusan Pembahagian Dimensi atau Komponen}

Hasil dapatan menunjukkan tiga dimensi atau komponen yang diekstrakkan ke atas 10 item pengetahuan guru dan 10 item tahap pelaksanaan PdP STEM. Manakala dua dimensi atau komponen terbentuk ke atas 10 item afektif guru dan 10 item motivasi guru. Berdasarkan keputusan analisis faktor yang dijalankan, kesemua item tidak disingkirkan kerana nilai muatan faktor bagi setiap item adalah melebihi 0.4 (Hair et al., 2010).

\section{Muatan faktor bagi setiap item}

Seterusnya, Jadual 8 menunjukkan muatan faktor bagi setiap komponen dalam setiap konstruk. Melalui Jadual -jadual ini, bilangan item bagi setiap komponen diperolehi. Dalam soal selidik yang digunakan, didapati bilangan item bagi setiap komponen adalah antara tiga hingga enam. Dapatan ini bersesuai dengan pendapat Pallant (2005) yang menyatakan minmum tiga item diperlukan untuk menerangkan satu komponen.

Jadual 8: Muatan Faktor Bagi Setiap Komponen

\begin{tabular}{ccccc}
\hline Konstruk & Item & 1 & 2 & 3 \\
\hline Pengetahuan & B3 & .926 & & \\
& B1 & .846 & & \\
B10 & .668 & .456 & \\
& B9 & .563 & & \\
B8 & & .904 & \\
B6 & & .775 & \\
B2 & & .675 & .619 \\
& B5 & & .480 & .773 \\
& B4 & & & .700 \\
& B7 & & & .591 \\
\hline Afektif & C1 & .936 & & \\
& C3 & .852 & & \\
& C10 & .812 & & \\
& C4 & .710 & .499 &
\end{tabular}




\begin{tabular}{|c|c|c|c|c|}
\hline & C6 & .696 & & \\
\hline & C9 & .598 & .453 & \\
\hline & $\mathrm{C} 7$ & .547 & .416 & \\
\hline & C5 & & .900 & \\
\hline & $\mathrm{C} 2$ & & .874 & \\
\hline & $\mathrm{C} 8$ & & .848 & \\
\hline \multirow[t]{10}{*}{ Motivasi } & D1 & .930 & & \\
\hline & D3 & .845 & & \\
\hline & D10 & .802 & & \\
\hline & D6 & .748 & & \\
\hline & D4 & .741 & .477 & \\
\hline & D9 & .646 & .427 & \\
\hline & D7 & .638 & & \\
\hline & D5 & & .907 & \\
\hline & D2 & & .882 & \\
\hline & D8 & .405 & .799 & \\
\hline \multirow[t]{10}{*}{ Pelaksanaan PdP STEM } & E6 & .888 & & \\
\hline & E8 & .826 & & \\
\hline & E2 & .766 & .502 & \\
\hline & E10 & .726 & & .542 \\
\hline & E7 & & .852 & \\
\hline & $\mathrm{E} 4$ & & .719 & .463 \\
\hline & E5 & .504 & .708 & \\
\hline & E1 & & .589 & \\
\hline & E9 & & & .897 \\
\hline & E3 & & .451 & .775 \\
\hline
\end{tabular}

Menurut Lay dan Khoo (2010), muatan faktor melebihi .60 dianggap tinggi manakala muatan faktor di bawah .40 dianggap rendah. Secara keseluruhannya, keputusan dalam Jadual 8 menunjukkan semua muatan faktor melebihi .40. Dalam kajian rintis ini, muatan faktor untuk setiap item adalah dalam julat 0.547 hingga 0.930 .

\section{Keputusan Analisis Cronbach's Alpha}

Analisis Cronbach's Alpha dijalankan untuk mendapatkan kebolehpercayaan instrumen yang digunakan. Nilai pekali Cronbach's alpha bagi keseluruhan item untuk pengetahuan guru (.840), afektif guru (.922), motivasi guru (.930) dan tahap pelaksanaan PdP STEM (.888). Dapatan ini menunjukkan hasil analisis mempunyai tahap kebolehpercayaan yang tinggi kerana nilai pekali melebihi 700 (Hinton et al., 2004).

\section{Perbincangan}

Kajian ini bertujuan untuk membangunkan instrumen PAMPDPSTEM yang boleh dipercayai dan sah untuk mengukur aspek pengetahuan, afektif dan motivasi guru terhadap pelaksanaan PdP STEM di sekolah menengah. Selepas melalui kesahan kandungan yang melibatkan empat orang pakar didapati kesemua 40 item sesuai digunakan untuk mengukur konstruk yang ingin dikaji.

Seterusnya, analisis faktor telah dijalankan untuk mendapat kesahan konstruk dan didapati nilai muatan faktor bagi setiap item adalah melebihi .40. Ini menunjukkan kesemua 40 item 
sah digunpakai bagi kajian sebenar. Manakala nilai kebolehpercayaan (alpha) bagi instrumen ini adalah dalam julat 0.840 hingga 0.930 . Dapatan ini menunjukkan instrumen mempunyai kebolehpercayaan yang tinggi.

Disamping itu, instrumen ini sangat ekonomikal dari segi masa kerana hanya mengandungi 40 item bagi menguji empat konstruk yang berbeza. Tatabahasa dan ayat yang digunakan juga adalah ringkas dan mudah difahami.

Dengan sedikit pengubahsuaian, instrumen ini sudah pasti boleh digunapakai oleh guru matematik, reka cipta dan teknologi maklumat dalam pelaksanaan PdP STEM. Ia juga boleh digunakan untuk menilai persepsi guru sekolah rendah bagi subjek yang berkaitan. Selain itu, instrumen ini turut diuji ke atas guru sains yang mengajar di sekolah harian biasa, sekolah agama dan sekolah berasrama penuh. Secara ringkasnya, instrumen ini boleh digunapakai oleh segenap responden. Pada ketika ini, belum wujud instrumen yang mengandungi soal selidik menggabungkan konstruk pengetahuan, afektif dan motivasi pelaksanaan PdP STEM di Malaysia.

\section{Kesimpulan}

Artikel ini melaporkan pembangunan dan pengesahan instrumen PAMPDPSTEM yang direka khas untuk menilai aspek pengetahuan, afektif dan motivasi guru sains terhadap pelaksanaan PdP STEM. Ia dibangunkan dengan menggunakan data persepsi guru sains untuk menilai tahap pelaksanaan PdP STEM di sekolah menengah. Secara keseluruhannya, hasil kajian ini mengesahkan kesahihan dan kebolehpercayaan instrumen PAMPDPSTEM dan membuktikan bahawa instrumen ini merupakan satu alat yang berguna untuk menilai pelaksanaan PdP STEM. Bagi memperhalusi lagi instrumen ini, penyelidikan yang lebih mendalam dan meluas diperlukan dengan melibatkan ciri-ciri demografi responden yang berbeza.

\section{Rujukan}

Abdul Halim Abdullah, Mohd Hilmi Hamzah, Raja Haffizah Soffia Raja Hussin, Umar Haiyat Abdul Kohar, Sharifah Nurarfah S. Abd Rahman \& Juhazren Junaidi (2017). Teachers' Readiness in Implementing Science, Technology, Engineering and Mathematics (STEM) Education from the Cognitive, Affective and Behavioural Aspects. IEEE 6th International Conference on Teaching Assessment, and Learning for Engineering (TALE), 112(1), 3-11.

Ahmad Zamri Khairani (2017). Assessing Urban and Rural Teachers' Competencies in STEM Intergrated Education in Malaysia. Tesis Sarjana, Pusat Pengajian Ilmu Pendidikan. Pulau Pinang: Univerisiti Sains Malaysia.

Amabile, T.M., Hill, K.G. Hennessey, B.A. \& Tighe, E.M. (1994). The Work Preference Inventory: Assessing Intrinsic and Extrinsic Motivational Orientations. Journal of Personality and Social Psychology, 66, 950-967.

An Gie Yong \& Pearce, S. (2013). A Beginner's Guide to Factor Analysis: Focusing on Exploratory Factor Analysis. Tutorials in Quantitative Methods for Psychology, 9(2), 79-94.

Chua Y. P. (2014). Kaedah dan Statistik Penyelidikan Bukul: Kaedah Penyelidikan .Shah Alam Selangor: Mac Graw Hill Education.

Edy Hafizan Mohd Shahali, Lilia Halim, Sattar Rasul, Kamisah Osman, Zanatun Ikhsan \& Faszly Rahim (2015). Bitara-STEM Training of Trainers' Programme: Impact on Trainers' Knowledge, Beliefs, Attitude and Efficacy towards Intergrated STEM Teaching, Journal of Baltic Science Education. 
Gorozidis, G. \& Papaioannou, A. G. (2013). Teachers' Motivation to Participate in Training and to Implement Innovations. Journal of Teaching and Teacher Education, 39, 1-11

Hair, J. F., Black, W.C., Babin, B.J. \& Anderson, R. E. (2010). Multivariate Data Analysis, 7th Edition. New York : Pearson.

Hinton, P. R., Brownlow, C., McMurray, I. \& Cozens, B. (2004). SPSS Explained. London and New York: Routledge.

Kementerian Pendidikan Malaysia. (2012). Pelan Pembangunan Pendidikan Malaysia 20132025. Putrajaya. Kementerian Pendidikan Malaysia.

Kementerian Pendidikan Malaysia. (2017). Panduan pelaksanaan STEM dalam PdP. Putrajaya. Bahagian Pembangunan Kurikulum.

Kementerian Pendidikan Malaysia. (2018). Laporan Tahunan 2017, Pelan Pembangunan Pendidikan Malaysia 2013-2025. Putrajaya. Kementerian Pendidikan Malaysia.

Kementerian Pendidikan Tinggi. (2017). Statistik Pendidikan Tinggi 2017. Putrajaya. Kementerian Pendidikan Tinggi.

Kubat, U. (2018). the Integration of STEM into Science Classes. World Journal on Educational Technology, Current Issues. 10(3), 165-173.

Lay Y.F. \& Khoo C. H. (2010). Pengenalan kepada Analisis Statistik dalam Penyelidikan Sains Sosial. Batu Caves Selangor: Venton Publishing (M) Sdn. Bhd.

Muhummad Abd Hadi Bunyamin (2014). Pendidikan STEM Bersepadu: Perspektif Global, Perkembangan Semasa di Malaysia dan Langkah ke Hadapan. Buletin Persatuan Pendidikan Sains dan Matematik Johor, 25(1), 1-6.

Nor Aishah Ahad, Teh S. Y., Abdul Rahman Othman \& Che Rohani Yaacob (2011). Sensitivity of Normality Tests to Non-normal Data. Sains Malaysiana, 40(6), 637641.

Nunnally, J. C. 1978. Psychometric Theory (2nd ed.). New York: McGraw-Hill

Nur Farhana Ramli, Othman Talib (2017). Can Education Institution Implement STEM? From Malaysian Teachers' View. International Journal of Academic Research in Business and Social Sciences, 7(3), 721-732.

Pallant, J. (2005).SPSS Survival Manual: A Step by Step Guide to Data Analysis Using SPSS for Windows (Version 12). Allen and Unwin, Crow's Nest NSW.

Pattamaporn Pimthong \& Williams, J. (2018). Pre Service Teachers' Understanding of STEM Education. Kasetsart Journal of Social Sciences.

Sandra van Aalderen-Smeets \& Juliette Walma van der Molen (2013) Measuring Primary Teachers' Attitudes Toward Teaching Science: Development of the Dimensions of Attitude Toward Science (DAS) Instrument, International Journal of Science Education, 35:4, 577-600

Siti Airunisa Alaui. (2017, Oktober 24). 493,830 saintis, jurutera diperlukan menjelang 2020. Utusan Malaysia. pp.47.

Stohlmann, M., Moore, T. J., \& Roehrig, G. H. (2012). Considerations for Teaching Integrated STEM Education. Journal of Pre-College Engineering Education Research (J-PEER), 2, 1-4.

Titik Rahayu, Syafrimen Syafril, Agus Pahrudin, Ibdal Satar, Kamisah Osman, Lilia Halim \& Nova Erlina Yaumas (2018). Mini Review . Solusi untuk Mempertingkatkan Kualiti Guru dalam Pembelajaran STEM di Sekolah Menengah: Universiti Kebangsaan Malaysia.

Walker, S. \& Fraser, B. (2005). Development and Validation of an Instrument Assessing Distance Education Learning Environment in Higher Education : The Distance Learning Environment Survey (DELES). Learning Environment Research: An International Journal, 8(3), 289-308. 